\title{
Implementasi Algoritma GLCM Dan MED pada Aplikasi Pendeteksi Kolesterol Melalui Iris Mata
}

\author{
Mira Musrini B ${ }^{[1]}$, Andriana ${ }^{[2]}$, Ari Seisar Hidayat ${ }^{[1]}$ \\ [1]]urusan Teknik Informatika, Fakultas Teknologi Industri \\ Institut Teknolgi Nasional Bandung \\ [2]Jurusan Teknik Elektro, Fakultas Teknik \\ Universitas Lalangbuana \\ Email: mira@itenas.ac.id
}

\begin{abstract}
ABSTRAK
Berdasarkan penelitian yang telah dilakukan dengan menggunakan gambar iris normal dan kolesterol sebagai input, metode GLCM (Gray Level Co-Occurrence Matrix) dapat digunakan pada aplikasi pendeteksi kolesterol melalui iris mata. Karena GLCM mampu memperoleh nilai fitur yang terdiri dari energi, entropi, homogenitas dan kontras dengan cara menghitung nilai probabilitas dari hasil perhitungan kemunculan matriks yang sama dalam piksel gambar dengan sudut( $\theta)$ 0 dan jarak(d) 1. Metode MED (Minimum Euclidean Distance) dapat digunakan untuk mengklasifikasi gambar iris normal dan kolesterol dengan menghitung nilai jarak Euclidean berdasarkan dari nilai fitur GLCM. Pembuatan aplikasi ini bertujuan untuk membantu orang-orang dengan mudah mendeteksi kolesterol secara cepat dan praktis tanpa harus pergi ke klinik atau rumah sakit. Pengujian yang dilakukan ke 24 orang dari gambar iris normal dan kolesterol dengan intensitas cahaya yang berbeda tingkat akurasi mencapai 70,83\%.
\end{abstract}

Kata kunci : Gray Level Co-Occurrence Matrix, Minimum Euclidean Distance

\begin{abstract}
Based on the research that has been done using iris image normal and cholesterol as input, the GLCM (Gray Level Co-Occurrence Matrix) method can be used in applications detection of cholesterol through the iris. Because GLCM able to obtain the value of features consisting of energy, entropy, homogeneity and contrast by calculating the probability value of the calculation result of the emergence of the same matrix pixel image with an angle $(\theta) 0^{\circ}$ and distance (d) 1. MED (The minimum Euclidean Distance) method can be used to classify normal and cholesterol iris image by calculating the Euclidean distance based on the value of the features GLCM. Making this application aims to help people easily detect cholesterol quickly and practically without having to go to a clinic or hospital. Tests were conducted to 24 people of normal and cholesterol iris images with different light intensities accuracy rate reached $70.83 \%$.
\end{abstract}

Keywords: Gray Level Co-Occurrence Matrix, Minimum Euclidean Distance 


\section{Pendahuluan}

GLCM merupakan salah satu ektraksi ciri untuk memperoleh nilai fitur dengan menghitung kemunculan matriks yang sama dalam piksel gambar. Fitur yang terdapat dalam GLCM terdiri dari energi, entropi, homogenitas, kontras, korelasi, mean, dissimilariti dsb. GLCM dapat digunakan untuk ekstraksi sebuah gambar. Karena masing-masing gambar berbeda-beda berdasarkan tekstur dan polanya. Misalnya gambar iris mata seseorang. Setiap orang mempunyai tekstur dan pola iris yang berbeda.

MED adalah suatu pengklasifikasi yang digunakan untuk menglasifikasikan suatu objek ke dalam suatu kelas pola tertentu berdasarkan pada perhitungan jarak Euclidean. Objek tersebut akan diklasifikasikan ke dalam kelas yang jarak antara prototype dari setiap kelas dan obyek yang akan diklasifikasikan tersebut terkecil. Objek bisa berupa gambar, sinyal, dsb.

Aplikasi pendeteksi kolesterol melalui iris mata adalah sebuah aplikasi yang mampu pendeteksi kolesetrol melalui iris mata seseorang. Aplikasi ini terdiri dari proses pelatihan dan pengujian.

Dengan menggunakan GLCM dan MED untuk aplikasi pendeteksi kolesterol melalui iris mata, diharapkan GLCM dapat mengekstraksi gambar dengan menghitung nilai fitur dari perhitungan kemunculan matriks yang sama dalam piksel gambar. Karena dalam penelitian ini input berupa gambar iris normal dan kolesterol. MED digunakan untuk mengklasifikasi objek gambar iris normal dan kolesterol berdasarkan pada perhitungan jarak Euclidean. Aplikasi ini diharapkan dapat membantu orang-orang agar mudah mendeteksi kolesterol secara cepat dan praktis tanpa harus pergi ke klinik atau rumah sakit.

\section{METODOLOGI PENELITIAN}

\section{$2.1 \mathrm{GLCM}$}

GLCM salah satu metode ekstraksi ciri untuk memperoleh nilai fitur dengan cara menghitung nilai probabilitas dari hasil perhitungan hubungan ketetanggaan antara dua piksel pada jarak dan orientasi sudut tertentu [5]. Pada Gambar 2 ditunjukan proses perhitungan matriks GLCM. Arah dan jarak GLCM dapat dilihat pada Gambar 1.

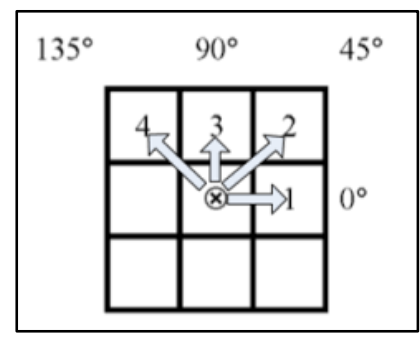

Gambar 1. Ilustrasi Sudut GLCM

(Sumber: Muhammad Dendi, 2014) 


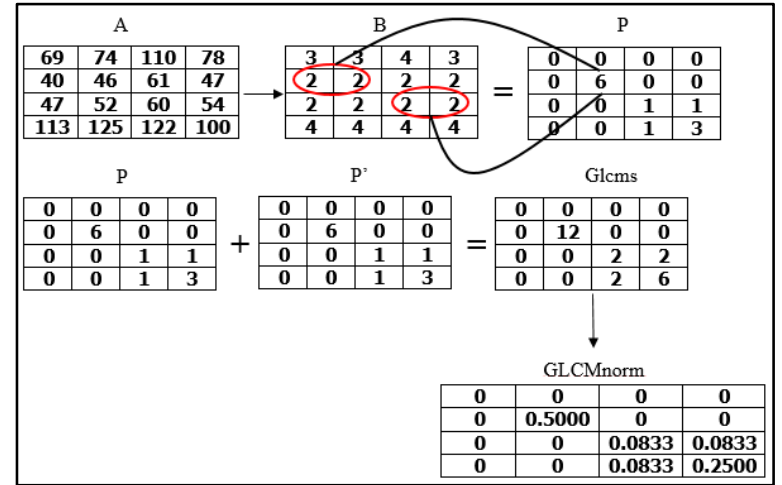

\section{Gambar 2. Ilustrasi Dari Langkah-langkah metode GLCM}

Ciri fitur statistik GLCM pada penelitian ini adalah sebagai berikut :

\section{Entropy}

Entropi digunakan untuk mengukur keteracakan dari distribusi intensitas [7]. Persamaan Entropy:

$$
\mathrm{E} 2=-\sum_{i}^{m} \sum_{j}^{n} p(i, j) \log \{p(i, j)\}
$$

\section{Dimana}

$$
\begin{array}{ll}
\mathrm{P} & =\text { matriks GLCM normalisasi } \\
\mathrm{i} & =\text { indeks baris matriks } P \\
\mathrm{j} & =\text { indeks kolom matriks } \mathrm{P}
\end{array}
$$

\section{Energy}

Energy/Energi merupakan fitur GLCM yang digunakan untuk mengukur konsentrasi pasangan intensitas pada matriks GLCM [7], dan didefinisikan sebagai berikut.

Persamaan Energy :

$$
\mathrm{H}=\sum_{i}^{m} \sum_{j}^{n} \frac{p(i, j)}{1+(i-j)^{2}}
$$

Dimana

$$
\begin{array}{ll}
\mathrm{P} & =\text { matriks GLCM normalisasi } \\
\mathrm{i} & =\text { indeks baris matriks } \mathrm{P} \\
\mathrm{j} & =\text { indeks kolom matriks } \mathrm{P}
\end{array}
$$

\section{Homogeneity}

Menunjukkan kehomogenan variasi intensitas dalam citra.

Persamaan Homogeneity sebagai berikut:

$$
E 1=\sum_{i}^{m} \sum_{j}^{n} P(i, j)^{2}
$$

Dimana

$$
\begin{array}{ll}
\mathrm{P} & =\text { matriks GLCM normalisasi } \\
\mathrm{i} & =\text { indeks baris matriks } \mathrm{P} \\
\mathrm{j} & =\text { indeks kolom matriks } \mathrm{P}
\end{array}
$$

\section{Contrast}

Kontras adalah perhitungan perbedaan intensitas antara piksel satu dan piksel yang berdekatan diseluruh gambar. Kontras bernilai nol untuk gambar yang konstan.

Persamaan Contrast :

$$
\mathrm{C} 2=\sum_{i=0}^{m} \sum_{j=0}^{n} P_{(i, j)}(i-j)^{2}
$$

Dimana 
$\mathrm{P} \quad=$ matriks GLCM normalisasi

$\mathrm{i} \quad=$ indeks baris matriks $\mathrm{P}$

$\mathrm{j} \quad=$ indeks kolom matriks $P$

\subsection{MED}

Metode Jarak Minimum adalah suatu pengklasifikasi yang digunakan untuk menglasifikasikan suatu objek ke dalam suatu kelas pola tertentu berdasarkan pada perhitungan jarak Euclidean. Objek tersebut akan diklasifikasikan ke dalam kelas yang jarak antara prototype dari setiap kelas dan obyek yang akan diklasifikasikan tersebut terkecil [8]. Perhitungan jarak menggunakan metode Euclidean dinyatakan sebagai berikut:

$$
d_{(x, y)}=\sqrt{\sum_{k=1}^{n}(x k-y k)^{2}}
$$

Dimana

$\mathrm{d}=$ nilai jarak euclidean

$\mathrm{x} \quad=$ data citra uji

$\mathrm{y}=$ data citra latih

$\mathrm{k} \quad=$ indeks

$(\mathrm{xk}, \mathrm{yk})=$ nilai dari setiap dimensi $\mathrm{k}$ pada $\mathrm{x}$ dan $\mathrm{y}$

\subsection{Cara Kerja Sistem}

Untuk menggambarkan langkah-langkah dan urutan prosedur dari Aplikasi Pendeteksi Kolesterol Melalui Iris Mata, secara umum maka dibuat sebuah model blok diagram kerja sistem aplikasi secara umum seperti pada Gambar 3.

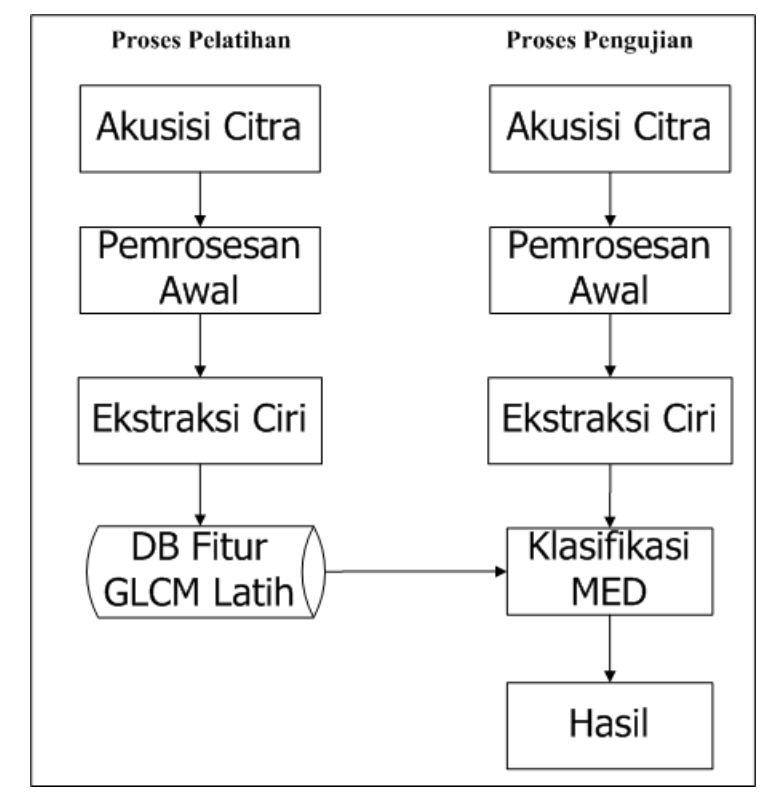

Gambar 3. Blok Diagram Cara Kerja Sistem

Pada Gambar 5 blok diagram citra latih dan citra uji memiliki tahapan yang sama, penjelasan dari tahapannya adalah sebagai berikut :

\subsubsection{Akuisisi}

Akuisisi citra merupakan proses untuk memilih citra masukan yang diperoleh dari mengambil citra pada direktori. 


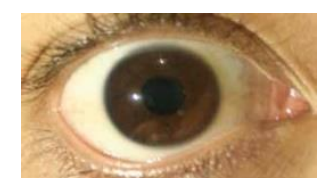

\section{Gambar 4. Citra Masukan}

\subsubsection{Tahap Pemrosesan Awal}

Pemrosesan awal dilakukan dengan mengubah citra dari RGB ke grayscale, mencari lingkaran pupil dan iris, serta pembentukan citra polar.

\section{Grayscale}

Dalam penelitian ini citra masukan hasil akuisisi memiliki 3 model layer warna (Red, Green, B/ue). Namun bila setiap proses perhitungan dilakukan menggunakan tiga layer, dapat diartikan dilakukan tiga perhitungan yang sama. Oleh karena itu dilakukan konversi citra dari 3 layer matriks RGB menjadi 1 layer matriks grayscale. Grayscale menggunakan persamaan berikut:

$$
I(i, y)=\alpha \cdot R+\beta \cdot G+\gamma \cdot B
$$

Keterangan:

$I(x, y)=$ level keabuan pada suatu koordinat

$\mathrm{R}=$ nilai warna merah

$\mathrm{G}=$ nilai warna hijau

$\mathrm{B}=$ nilai warna biru

Dengan nilai konstanta $a=0.2989, \beta=0.5870, \gamma=0.1140$

(Mulkan syarif, 2012)

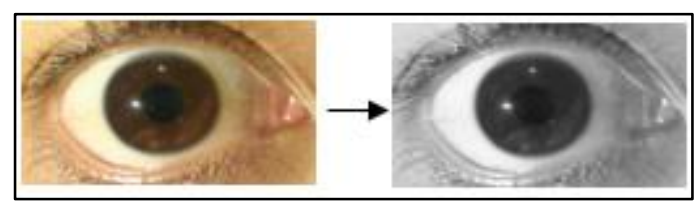

Gambar 5 - Konversi Citra RGB ke Grayscale

Contoh penerapan coding Matlabnya adalah sebagai berikut:

im=rgb2gray(imread(file));

\subsubsection{Deteksi lingkaran iris dan pupil}

Pada Proses ini bertujuan untuk mendapatkan lingkaran iris dan pupil yang akan diolah lebih lanjut. Sebelum mendapatkan ligkaran iris dan pupil, dilakukan terlebih dahulu proses pencarian letak pupil, pencarian titik tengah pupil, pencarian jari-jari pupil, dan pencarian panjang jari-jari iris. Untuk prosesnya ditunjukan pada Gambar 6. 


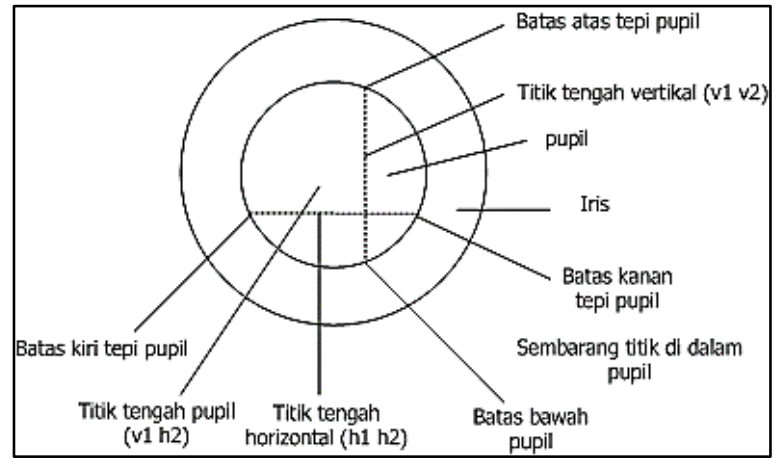

Gambar 6. Ilustrasi Proses Pencarian Lingkaran iris dan Pupil (Sumber: Eskaprianda, Ardianto 2013)

hasil akhir dari proses pencarian lingkaran iris dan pupil akan seperti pada Gambar 7.

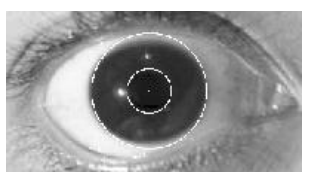

\section{Gambar 7. Hasil Deteksi Lingkaran Iris dan Pupil}

\subsubsection{Pembentukan citra polar}

Citra pupil dan iris mata yang berbentuk lingkaran diubah menjadi bentuk polar $(r, \theta)$ dengan ukuran yang tetap Prosesnya pembentukan citra polar ditunjukan pada Gambar 8.

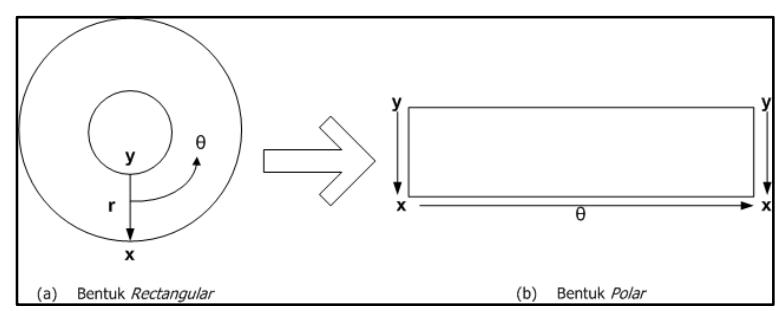

Gambar 8. Proses Pengubahan Citra Lingkaran mata ke bentuk Polar (Sumber: Eskaprianda, Ardianto 2013)

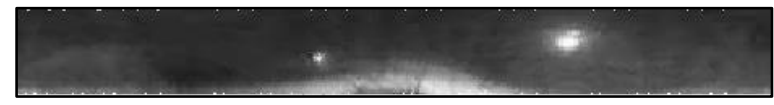

Gambar 9. Hasil Citra Polar

$$
\begin{aligned}
& x=r \cos \theta+a \\
& y=r \sin \theta+a
\end{aligned}
$$

Keterangan:

$r$ = jari-jari lingkaran

$\mathrm{x}=$ koordinat titik $\mathrm{x}$

$y=$ koordinat titik $y$

$\theta$ = sudut

persamaan polar dari lingkaran berjari-jari $a: \mathrm{r}=a$

untuk lingkaran berjari $a$,

- $\mathrm{x}$ : berpusat $\operatorname{di}(0, a): \mathrm{r}=1 a \cos \theta$

- $\mathrm{y}$ : berpusat di $(a, 0): \mathrm{r}=1 a \sin \theta$

pusat lingkaran $(0,0)$

$\mathrm{x}=1.1$ 
$x=1$

$y=1.0$

$y=0$

jadi persamaan tersebut dalam koordinat tegak 0 sampai 1

\subsubsection{Resizing}

Pada proses ini bertujuan untuk merubah ukuran matriks pada piksel citra polar yang ukurannya besar ke ukuran kecil yaitu 8x8. Dilakukan dengan cara menyisipkan sourcecode sebagai berikut :

gbr=imresize(rectangular,[8 8]);

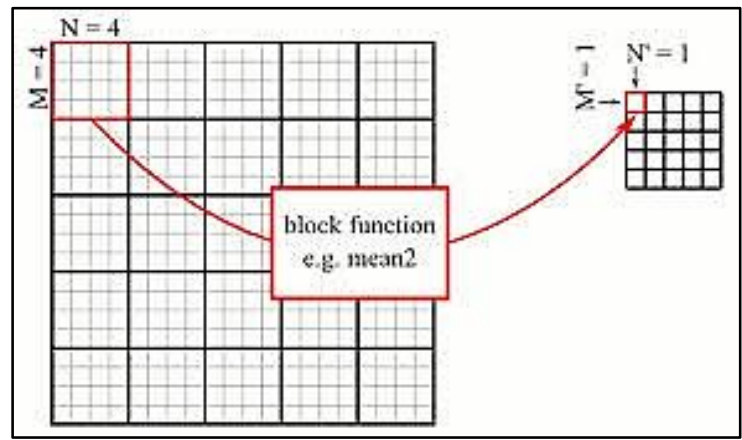

Gambar 10 - Proses resize image

(Sumber: http://www.peteryu.ca/tutorials/matlab/blockaverage)

Penjelasan dari Gambar 10 dimana matriks piksel gambar dalam ukuran M baris dengan kolom N. Pada kasus diatas adalah ilustrasi dari porses resizing image, Gambar 10 sebelah kiri adalah matriks citra asli dimana ukuran matriks piksel dengan ukuran awal adalah 20x20. Kemudian diubah ke bentuk ukuran $5 \times 5$ pada Gambar 10 sebelah kanan. Dalam penelitian ini matriks piksel diubah ke bentuk ukuran $8 \times 8$. Proses dari resizing image ditunjukan pada Gambar 11

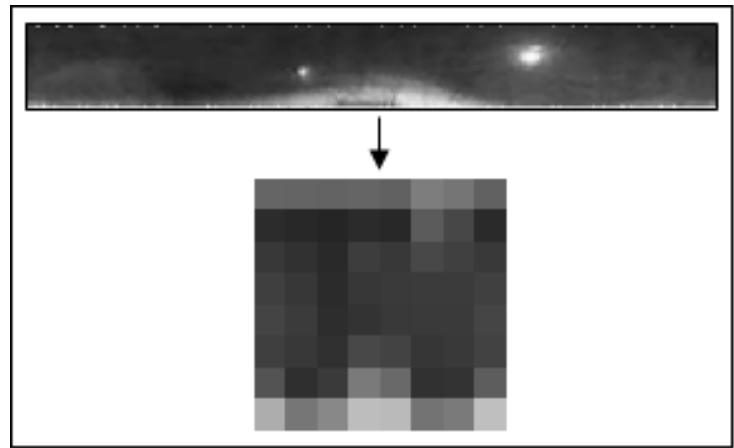

Gambar 11. Proses Resize Citra Polar Ke Ukuran 8x8

\subsection{Tahap Ekstraksi Ciri}

Berikut ini adalah alur dari proses ekstraksi ciri GLCM: 


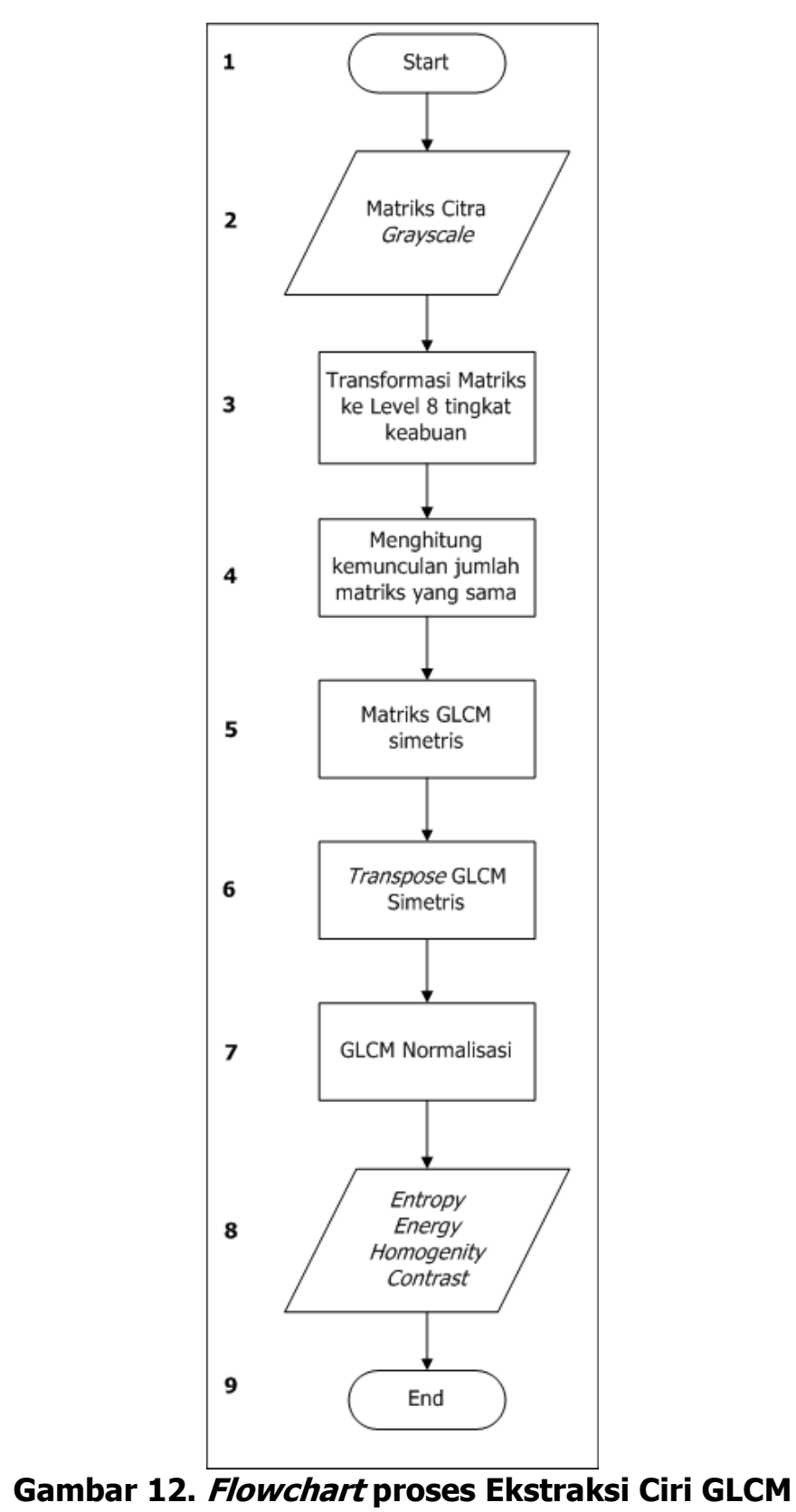

Ekstraksi ciri ini dilakukan untuk mendapatkan fitur statistik dari GLCM. Tahapan dari ekstraksi ciri GLCM adalah sebagai berikut :

1. Mengambil matriks citra grayscale

Dilakukan dengan cara menyisipkan sourcecode sebagai berikut :

Matriks_Citra=uint8(gbr)

Perintah sourcecode digunakan untuk menampilkan matrik pada masing-masing grayscale. Array dari kelas uint8. lebar nilai dari $0-2^{8}-1$ fungsi uint8 memetakan nilai apa pun pada array yang berada diluar batas terdekat proses final untuk contoh, uint8 $\left(2^{8}\right)=256$

$256-1=255$ 


\begin{tabular}{|rrrrrrrr|}
\hline \multicolumn{7}{c|}{ A } \\
101 & 100 & 99 & 101 & 97 & 125 & 117 & 97 \\
44 & 40 & 37 & 43 & 40 & 91 & 71 & 42 \\
56 & 49 & 41 & 61 & 56 & 72 & 64 & 57 \\
63 & 55 & 43 & 55 & 58 & 59 & 59 & 64 \\
68 & 59 & 45 & 51 & 57 & 58 & 58 & 69 \\
63 & 56 & 48 & 72 & 67 & 54 & 57 & 66 \\
83 & 47 & 58 & 122 & 105 & 49 & 51 & 93 \\
173 & 118 & 136 & 189 & 186 & 115 & 122 & 191 \\
\end{tabular}

Gambar 13. Matriks Citra grayscale

2. Proses transformasi warna rata-rata matriks piksel ke 8 variasi derjat keabuan. Pada Gambar 14 adalah hasil dari proses transformasi warna rata-rata matriks piksel graycale ke derajat keabuan. Untuk lebih jelasnya Tabel 1 menunjukan tingkatan warna grayscale ke dalam derajat keabuan.

\begin{tabular}{|llllllll|}
\hline & \multicolumn{7}{c|}{ B } \\
4 & 4 & 4 & 4 & 4 & 4 & 4 & 4 \\
2 & 2 & 2 & 2 & 2 & 3 & 3 & 2 \\
2 & 2 & 2 & 2 & 2 & 3 & 3 & 2 \\
2 & 2 & 2 & 2 & 2 & 2 & 2 & 3 \\
3 & 2 & 2 & 2 & 2 & 2 & 2 & 3 \\
2 & 2 & 2 & 3 & 3 & 2 & 2 & 3 \\
3 & 2 & 2 & 4 & 4 & 2 & 2 & 3 \\
6 & 4 & 5 & 6 & 6 & 4 & 4 & 6 \\
\hline
\end{tabular}

\section{Gambar 14. Perubahan Matriks Grayscale Ke 8 Tingkat Keabuan}

Tabel 1. Transformasi warna grayscale ke 8 variasi derajat keabuan

(Sumber: Maharani, Fina 2013)

\begin{tabular}{|l|l|}
\hline Level & \multicolumn{1}{|c|}{ Nilai } \\
\hline 1 & $0-31$ \\
\hline 2 & $32-63$ \\
\hline 3 & $64-95$ \\
\hline 4 & $96-127$ \\
\hline 5 & $128-159$ \\
\hline 6 & $160-191$ \\
\hline 7 & $192-223$ \\
\hline 8 & $224-256$ \\
\hline
\end{tabular}

3. Menghitung kemunculan jumlah matriks yang sama

Hasil dari proses transformasi warna matriks piksel grayscale ke 8 variasi derjat keabuan, kemudian akan dihitung jumlah kemunculan matriks yang sama. Pada Gambar 15 untuk matriks $B$ jumlah kemunculan matriks yang sama (4 2) adalah 1 . Matriks $C$ adalah matriks GLCM dari hasil perhtungan kemunculan matriks yang sama dari matriks $B$. 


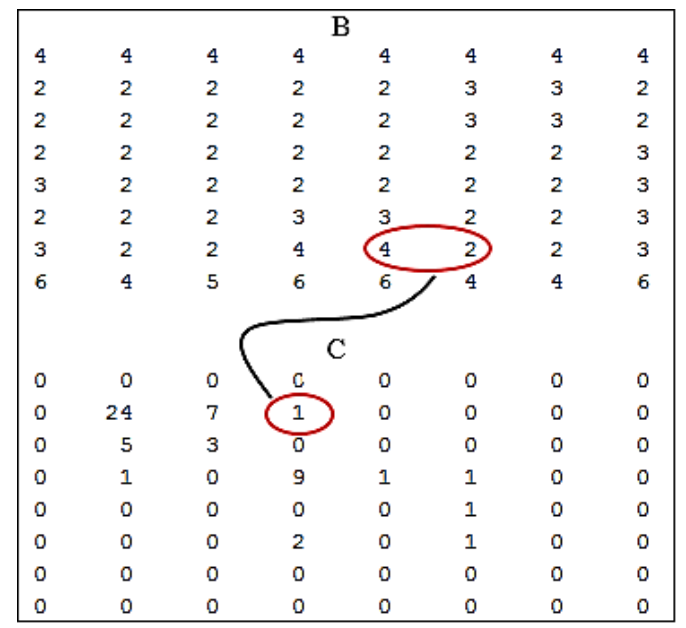

Gambar 15. Proses Perhitungan Kemunculan Matriks yang sama

4. Menjumlahkan matriks GLCM dengan tranposenya untuk menjadikannya simetris. Pada Gambar 16 untuk B adalah matriks GLCM dan E adalah hasil transpose dari matriks GLCM. Sedangkan pada Gambar 17 adalah matriks GLCM simetris hasil dari penjumlahan matriks B dan $\mathrm{E}$.

\begin{tabular}{|c|c|c|c|c|c|c|c|}
\hline \multicolumn{8}{|c|}{ B } \\
\hline 0 & 0 & 0 & 0 & 0 & 0 & 0 & 0 \\
\hline 0 & 24 & 7 & 1 & 0 & 0 & 0 & 0 \\
\hline 0 & 5 & 3 & 0 & 0 & 0 & 0 & 0 \\
\hline 0 & 1 & 0 & 9 & 1 & 1 & 0 & 0 \\
\hline 0 & 0 & 0 & 0 & 0 & 1 & 0 & 0 \\
\hline 0 & 0 & 0 & 2 & 0 & 1 & 0 & 0 \\
\hline 0 & 0 & 0 & 0 & 0 & 0 & 0 & 0 \\
\hline 0 & 0 & 0 & 0 & 0 & 0 & 0 & 0 \\
\hline \multicolumn{8}{|c|}{+} \\
\hline \multicolumn{8}{|c|}{$\mathrm{E}$} \\
\hline 0 & 0 & 0 & 0 & 0 & 0 & 0 & 0 \\
\hline 0 & 24 & 5 & 1 & 0 & 0 & 0 & 0 \\
\hline 0 & 7 & 3 & 0 & 0 & 0 & 0 & 0 \\
\hline 0 & 1 & 0 & 9 & 0 & 2 & 0 & 0 \\
\hline 0 & 0 & 0 & 1 & 0 & 0 & 0 & 0 \\
\hline 0 & 0 & 0 & 1 & 1 & 1 & 0 & 0 \\
\hline 0 & 0 & 0 & 0 & 0 & 0 & 0 & 0 \\
\hline 0 & 0 & 0 & 0 & 0 & 0 & 0 & 0 \\
\hline
\end{tabular}

Gambar 16. Menjumlahkan Matriks GLCM dan Matriks Transpose

\begin{tabular}{|rrrrllll|}
\hline 0 & 0 & 0 & 0 & 0 & 0 & 0 & 0 \\
0 & 48 & 12 & 2 & 0 & 0 & 0 & 0 \\
0 & 12 & 6 & 0 & 0 & 0 & 0 & 0 \\
0 & 2 & 0 & 18 & 1 & 3 & 0 & 0 \\
0 & 0 & 0 & 1 & 0 & 1 & 0 & 0 \\
0 & 0 & 0 & 3 & 1 & 2 & 0 & 0 \\
0 & 0 & 0 & 0 & 0 & 0 & 0 & 0 \\
0 & 0 & 0 & 0 & 0 & 0 & 0 & 0 \\
\hline
\end{tabular}

Gambar 17. Hasil Matriks GLCM simetris

5. Normalisasi matriks dengan mengubah nilai matriks menjadi nilai statistik. Pada Gambar 18 Nilai dari 0,4286 didapat dari hasil perhitungan dari matriks GLCMs jumlah 48 dibagi dengan hasil keseluruhan matriks GLCMs yaitu 112. Demikian juga dengan Angka statistik yang lainnya pada matriks normalisasi caranya seperti itu. 


\begin{tabular}{|l|c|c|c|c|c|c|c|}
\hline $\mathbf{0}$ & $\mathbf{0}$ & $\mathbf{0}$ & $\mathbf{0}$ & $\mathbf{0}$ & $\mathbf{0}$ & $\mathbf{0}$ & $\mathbf{0}$ \\
\hline $\mathbf{0}$ & $\mathbf{0 , 4 2 8 6}$ & $\mathbf{0 , 1 0 7 1}$ & $\mathbf{0 . 0 1 7 9}$ & $\mathbf{0}$ & $\mathbf{0}$ & $\mathbf{0}$ & $\mathbf{0}$ \\
\hline $\mathbf{0}$ & $\mathbf{0 , 1 0 7 1}$ & $\mathbf{0 , 0 5 3 6}$ & $\mathbf{0}$ & $\mathbf{0}$ & $\mathbf{0}$ & $\mathbf{0}$ & $\mathbf{0}$ \\
\hline $\mathbf{0}$ & $\mathbf{0 , 0 1 7 9}$ & $\mathbf{0}$ & $\mathbf{0 , 1 6 0 7}$ & $\mathbf{0 , 0 0 8 9}$ & $\mathbf{0 , 0 2 6 8}$ & $\mathbf{0}$ & $\mathbf{0}$ \\
\hline $\mathbf{0}$ & $\mathbf{0}$ & $\mathbf{0}$ & $\mathbf{0 , 0 0 8 9}$ & $\mathbf{0}$ & $\mathbf{0 , 0 0 8 9}$ & $\mathbf{0}$ & $\mathbf{0}$ \\
\hline $\mathbf{0}$ & $\mathbf{0}$ & & $\mathbf{0 , 0 2 6 8}$ & $\mathbf{0 , 0 0 8 9}$ & $\mathbf{0 , 0 1 7 9}$ & $\mathbf{0}$ & $\mathbf{0}$ \\
\hline $\mathbf{0}$ & $\mathbf{0}$ & $\mathbf{0}$ & & $\mathbf{0}$ & $\mathbf{0}$ & $\mathbf{0}$ & $\mathbf{0}$ \\
\hline $\mathbf{0}$ & $\mathbf{0}$ & $\mathbf{0}$ & $\mathbf{0}$ & $\mathbf{0}$ & $\mathbf{0}$ & $\mathbf{0}$ & $\mathbf{0}$ \\
\hline
\end{tabular}

Gambar 18. Hasil Matriks Normalisasi

6. Menghitung fitur GLCM energy, entropi, homogenitas, kontras.

\subsection{Tahap Klasifikasi}

Algoritma pada proses klasifikasi dijelaskan pada flowchart Gambar 11.

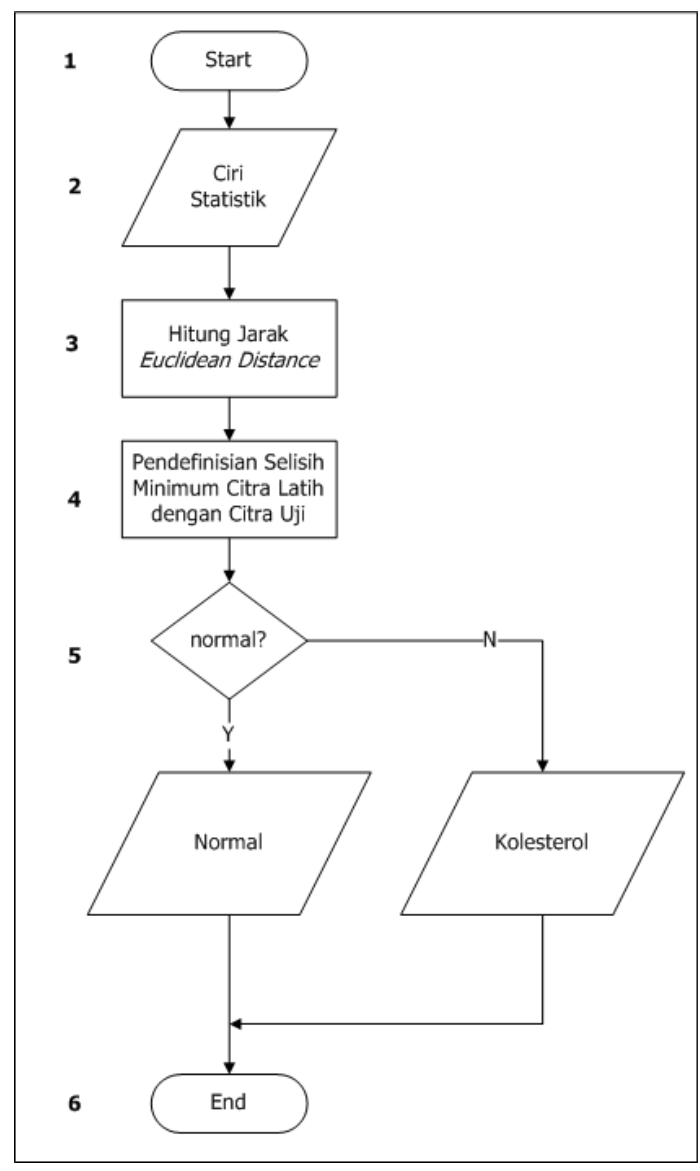

Gambar 19.Flowchart proses Klasifikasi

Penjelasan dari Gambar 19, nilai ciri statistik dari GLCM kemudian akan dihitung dengan jarak Eulidean Distance sehingga akan didapatkan nilai jarak Euclideamya. Setelah itu pendefinisian selisih Minimum citra latih dengan citra uji. Lalu akan keluar hasil antara normal atau kolesterol.

Proses klasifikasi dilakukan dengan membandingkan fitur citra uji dengan fitur citra latih menggunakan metode MED. Perhitungan jarak Euclidean Distance. Berikut adalah perhiungan dari Eulcidean Distance:

Terdapat 2 buah nilai dari Fitur GLCM dengan ruang Euclidean distance 4 dimensi sebagai berikut :

$$
\begin{array}{ll}
\text { Latih } & =[0,2428,1,8420,0,8196,0,6071] \\
\text { Uji } & =[0,2380,1,8704,0,8036,0,4464]
\end{array}
$$


perhitungan nilai Euclidean Distance :

$$
\begin{aligned}
& E=\sqrt{\begin{array}{c}
(0,2428-0,2380)^{2}+(1,8420-1,8304)^{2}+ \\
(0,8196-0,8036)^{2}+(0,6071-0,4464)^{2}
\end{array}} \\
& =\sqrt{\begin{array}{c}
0,00002304+0,00013456+ \\
0,000256+0,02582449
\end{array}} \\
& =0,1619
\end{aligned}
$$

Nilai Data uji yang dihitung jaraknya dengan data latih adalah 0,1619.

\section{ANALISIS DAN PEMBAHASAN}

\subsection{Pengujian Ekstraksi Ciri Data Latih}

Pengujian ini adalah proses untuk mendapatkan fitur GLCM dari hasil ekstraksi ciri dari citra

\begin{tabular}{|c|c|c|c|}
\hline Berkas & Parameter & $\begin{array}{l}\text { Jarak } \\
d\end{array}$ & $\begin{array}{l}\text { Sudut } \\
\begin{array}{ll}\theta 0^{\circ}\end{array}\end{array}$ \\
\hline \multirow{4}{*}{ Ari } & Entropy & \multirow{4}{*}{1} & 2,287 \\
\hline & Energy & & $\begin{array}{l}0,152 \\
6\end{array}$ \\
\hline & $\begin{array}{l}\text { Homogeneit } \\
y\end{array}$ & & $\begin{array}{l}0,744 \\
0\end{array}$ \\
\hline & Contrast & & $\begin{array}{l}0,750 \\
0\end{array}$ \\
\hline \multirow{4}{*}{ Pa tete } & Entropy & \multirow{4}{*}{1} & $\begin{array}{l}2,081 \\
0\end{array}$ \\
\hline & Energy & & $\begin{array}{l}0,191 \\
8\end{array}$ \\
\hline & $\begin{array}{l}\text { Homogeneit } \\
y\end{array}$ & & $\begin{array}{l}0,797 \\
6\end{array}$ \\
\hline & Contrast & & $\begin{array}{l}0,767 \\
9\end{array}$ \\
\hline \multirow{4}{*}{ Bu Jaja } & Entropy & \multirow{4}{*}{1} & $\begin{array}{l}2,400 \\
0\end{array}$ \\
\hline & Energy & & $\begin{array}{l}0,151 \\
0\end{array}$ \\
\hline & $\begin{array}{l}\text { Homogeneit } \\
y\end{array}$ & & $\begin{array}{l}0,785 \\
7\end{array}$ \\
\hline & Contrast & & $\begin{array}{l}0,571 \\
4\end{array}$ \\
\hline \multirow{4}{*}{ Bu Papat } & Entropy & \multirow{4}{*}{1} & $\begin{array}{l}2,025 \\
3\end{array}$ \\
\hline & Energy & & $\begin{array}{l}0,226 \\
6\end{array}$ \\
\hline & $\begin{array}{l}\text { Homogeneit } \\
y\end{array}$ & & $\begin{array}{l}0,827 \\
4\end{array}$ \\
\hline & Contrast & & $\begin{array}{l}0,392 \\
9\end{array}$ \\
\hline \multirow{2}{*}{ Bu Rais } & Entropy & \multirow{2}{*}{1} & $\begin{array}{l}1,705 \\
0\end{array}$ \\
\hline & Energy & & $\begin{array}{l}0,364 \\
3\end{array}$ \\
\hline
\end{tabular}
latih. Untuk lebih jelasnya akan di jelaskan pada Tabel 1.

Tabel 2. Data latih yang diperoleh dari ekstraksi ciri GLCM 
Implementasi Algoritma GLCM Dan MED pada Aplikasi Pendeteksi Kolesterol Melalui Iris Mata

\begin{tabular}{|c|c|c|c|}
\hline Berkas & Parameter & $\begin{array}{l}\text { Jarak } \\
d\end{array}$ & $\begin{array}{l}\text { Sudut } \\
\theta 0^{\circ}\end{array}$ \\
\hline & $\begin{array}{l}\text { Homogeneit } \\
y\end{array}$ & & $\begin{array}{l}0,863 \\
1\end{array}$ \\
\hline & Contrast & & $\begin{array}{l}0,321 \\
4\end{array}$ \\
\hline \multirow{4}{*}{ Bu Teti } & Entropy & \multirow{4}{*}{1} & 1,978 \\
\hline & Energy & & $\begin{array}{l}0,236 \\
9\end{array}$ \\
\hline & $\begin{array}{l}\text { Homogeneit } \\
y\end{array}$ & & $\begin{array}{l}0,815 \\
5\end{array}$ \\
\hline & Contrast & & $\begin{array}{l}0,464 \\
3\end{array}$ \\
\hline \multirow{4}{*}{ Teh Lia } & Entropy & \multirow{4}{*}{1} & $\begin{array}{l}1,806 \\
6\end{array}$ \\
\hline & Energy & & $\begin{array}{l}0,270 \\
4\end{array}$ \\
\hline & $\begin{array}{l}\text { Homogeneit } \\
y\end{array}$ & & $\begin{array}{l}0,886 \\
9 \\
\end{array}$ \\
\hline & Contrast & & $\begin{array}{l}0,321 \\
4\end{array}$ \\
\hline \multirow{4}{*}{ Teh Medi } & Entropy & \multirow{4}{*}{1} & $\begin{array}{l}1,724 \\
0\end{array}$ \\
\hline & Energy & & $\begin{array}{l}0,246 \\
8\end{array}$ \\
\hline & $\begin{array}{l}\text { Homogeneit } \\
y\end{array}$ & & $\begin{array}{l}0,864 \\
6 \\
\end{array}$ \\
\hline & Contrast & & $\begin{array}{l}0,500 \\
0\end{array}$ \\
\hline \multirow{4}{*}{ Pa Ade } & Entropy & \multirow{4}{*}{1} & $\begin{array}{l}2,016 \\
0\end{array}$ \\
\hline & Energy & & $\begin{array}{l}0,184 \\
3\end{array}$ \\
\hline & $\begin{array}{l}\text { Homogeneit } \\
y\end{array}$ & & $\begin{array}{l}0,848 \\
2\end{array}$ \\
\hline & Contrast & & $\begin{array}{l}0,446 \\
4\end{array}$ \\
\hline \multirow{4}{*}{ Puteri } & Entropy & \multirow{4}{*}{1} & $\begin{array}{l}1,776 \\
3\end{array}$ \\
\hline & Energy & & $\begin{array}{l}0,328 \\
0\end{array}$ \\
\hline & $\begin{array}{l}\text { Homogeneit } \\
y\end{array}$ & & $\begin{array}{l}0,872 \\
0\end{array}$ \\
\hline & Contrast & & $\begin{array}{l}0,571 \\
4\end{array}$ \\
\hline \multirow{4}{*}{ Soimah } & Entropy & \multirow{4}{*}{1} & $\begin{array}{l}1,842 \\
0\end{array}$ \\
\hline & Energy & & $\begin{array}{l}0,242 \\
8\end{array}$ \\
\hline & $\begin{array}{l}\text { Homogeneit } \\
y\end{array}$ & & $\begin{array}{l}0,824 \\
4\end{array}$ \\
\hline & Contrast & & $\begin{array}{l}0,446 \\
4\end{array}$ \\
\hline
\end{tabular}

Hasil pengujian ekstraksi untuk citra latih kemudian nilai dari fitur GLCM akan disimpan kedalam format.mat pada matlab. Nilai fitur GLCM ini digunakan sebagai data latih yang 
nantinya akan dihitung jaraknya dengan nilai fitur dari citra uji menggunakan euclidean distance.

\subsection{Pengujian Klasifikasi Data Latih}

Tabel 3 - Hasil pengujian MED pada data latih

\begin{tabular}{|l|l|l|l|}
\hline Berkas & $\begin{array}{l}\text { Nilai } \\
\text { Euclidean }\end{array}$ & Harapan & Kondisi \\
\hline Ari & 0 & Kolesterol & Kolesterol \\
\hline Pa tete & 0 & Kolesterol & Kolesterol \\
\hline Bu Jaja & 0 & Kolesterol & Kolesterol \\
\hline Bu Papat & 0 & Kolesterol & Kolesterol \\
\hline Bu Rais & 0 & Kolesterol & Kolesterol \\
\hline Bu Teti & 0 & Kolesterol & Kolesterol \\
\hline Teh Lia & 0 & Normal & Normal \\
\hline $\begin{array}{l}\text { Teh } \\
\text { Medi }\end{array}$ & 0 & Normal & Normal \\
\hline Pa Ade & 0 & Kolesterol & Kolesterol \\
\hline Puteri & 0 & Normal & Normal \\
\hline Soimah & 0 & Normal & Normal \\
\hline
\end{tabular}

\subsection{Pengujian Ekstraksi Ciri Data Uji}

Tabel 4 - Data uji yang diperoleh dari ekstraksi ciri GLCM

\begin{tabular}{|c|c|c|c|}
\hline Berkas & Parameter & $\begin{array}{l}\text { Jarak } \\
d\end{array}$ & $\begin{array}{l}\text { Sudut } \theta \\
0^{\circ}\end{array}$ \\
\hline \multirow{4}{*}{ Rifqi } & Entropy & \multirow{4}{*}{1} & 2,0258 \\
\hline & Energy & & 0,3571 \\
\hline & $\begin{array}{l}\text { Homogeneit } \\
y\end{array}$ & & 0,8125 \\
\hline & Contrast & & 0,3750 \\
\hline \multirow{4}{*}{ Bu Kikim } & Entropy & \multirow{4}{*}{1} & 0,1607 \\
\hline & Energy & & 2,3431 \\
\hline & $\begin{array}{l}\text { Homogeneit } \\
y\end{array}$ & & 0,7827 \\
\hline & Contrast & & 0,4821 \\
\hline \multirow{4}{*}{ Bu Toha } & Entropy & \multirow{4}{*}{1} & 2,2669 \\
\hline & Energy & & 0,1537 \\
\hline & Homogeneit & & 0,7119 \\
\hline & Contrast & & 1,0714 \\
\hline \multirow{4}{*}{ Bu Ema } & Entropy & \multirow{4}{*}{1} & 1,8871 \\
\hline & Energy & & 0,3402 \\
\hline & Homogeneit & & 0,8268 \\
\hline & Contrast & & 0,7321 \\
\hline \multirow{3}{*}{ Bu Rais } & Entropy & \multirow{3}{*}{1} & 2,4208 \\
\hline & Energy & & 0,1352 \\
\hline & $\begin{array}{l}\text { Homogeneit } \\
\text { y }\end{array}$ & & 0,8393 \\
\hline
\end{tabular}


Implementasi Algoritma GLCM Dan MED pada Aplikasi Pendeteksi Kolesterol Melalui Iris Mata

\begin{tabular}{|c|c|c|c|}
\hline Berkas & Parameter & \begin{tabular}{|l|} 
Jarak \\
$d$
\end{tabular} & $\begin{array}{l}\text { Sudut } \theta \\
0^{\circ}\end{array}$ \\
\hline & Contrast & & 1,3750 \\
\hline \multirow{4}{*}{ Bu Ruslan } & Entropy & \multirow{4}{*}{1} & 2,4208 \\
\hline & Energy & & 0,1352 \\
\hline & Homogeneit & & 0,6994 \\
\hline & \begin{tabular}{|l} 
Contrast \\
\end{tabular} & & 1,3750 \\
\hline \multirow{4}{*}{ Bu Setiono } & Entropy & \multirow{4}{*}{1} & 2,0479 \\
\hline & Energy & & 0,2296 \\
\hline & $\begin{array}{l}\text { Homogeneit } \\
y\end{array}$ & & 0,7917 \\
\hline & Contrast & & 0,6071 \\
\hline \multirow{4}{*}{ Bu Tri } & Entropy & \multirow{4}{*}{1} & 2,0879 \\
\hline & Energy & & 0,2090 \\
\hline & $\begin{array}{l}\text { Homogeneit } \\
y\end{array}$ & & 0,8244 \\
\hline & Contrast & & 0,4464 \\
\hline \multirow{4}{*}{ Pa Arya } & Entropy & \multirow{4}{*}{1} & 2,2612 \\
\hline & Energy & & 0,1425 \\
\hline & $\begin{array}{l}\text { Homogeneit } \\
y\end{array}$ & & 0,8185 \\
\hline & Contrast & & \begin{tabular}{|l|}
0,4107 \\
\end{tabular} \\
\hline \multirow{4}{*}{ Pa Ero } & Entropy & \multirow{4}{*}{1} & 2,1587 \\
\hline & Energy & & 0,1604 \\
\hline & $\begin{array}{l}\text { Homogeneit } \\
y\end{array}$ & & 0,7827 \\
\hline & Contrast & & 0,4821 \\
\hline \multirow{4}{*}{ Pa Hilman } & Entropy & \multirow{4}{*}{1} & 2,6401 \\
\hline & Energy & & 0,1073 \\
\hline & $\begin{array}{l}\text { Homogeneit } \\
y\end{array}$ & & 0,6955 \\
\hline & Contrast & & 1,2857 \\
\hline \multirow{4}{*}{ Pa Yudi } & Entropy & \multirow{4}{*}{1} & 2,0527 \\
\hline & Energy & & 0,8172 \\
\hline & $\begin{array}{l}\text { Homogeneit } \\
y\end{array}$ & & 0,8185 \\
\hline & Contrast & & 0,4107 \\
\hline \multirow{4}{*}{ Oni } & Entropy & \multirow{4}{*}{1} & 1 \\
\hline & Energy & & $-2,2204$ \\
\hline & Homogeneit & & 1 \\
\hline & Contrast & & 0 \\
\hline \multirow{4}{*}{ Bu Andi } & Entropy & \multirow{4}{*}{1} & - \\
\hline & Energy & & - \\
\hline & Homogeneit & & - \\
\hline & $\begin{array}{l}\mathrm{y} \\
\text { Contrast }\end{array}$ & & \begin{tabular}{|l} 
\\
-
\end{tabular} \\
\hline \multirow{4}{*}{ Bu Nenden } & Entropy & \multirow{4}{*}{1} & - \\
\hline & Energy & & - \\
\hline & Homogeneit & & - \\
\hline & Contrast & & - \\
\hline \multirow{3}{*}{ Dian } & Entropy & \multirow{3}{*}{1} & 2,0661 \\
\hline & Energy & & 0,1569 \\
\hline & $\begin{array}{l}\text { Homogeneit } \\
y\end{array}$ & & 0,8006 \\
\hline
\end{tabular}

MIND - 37 


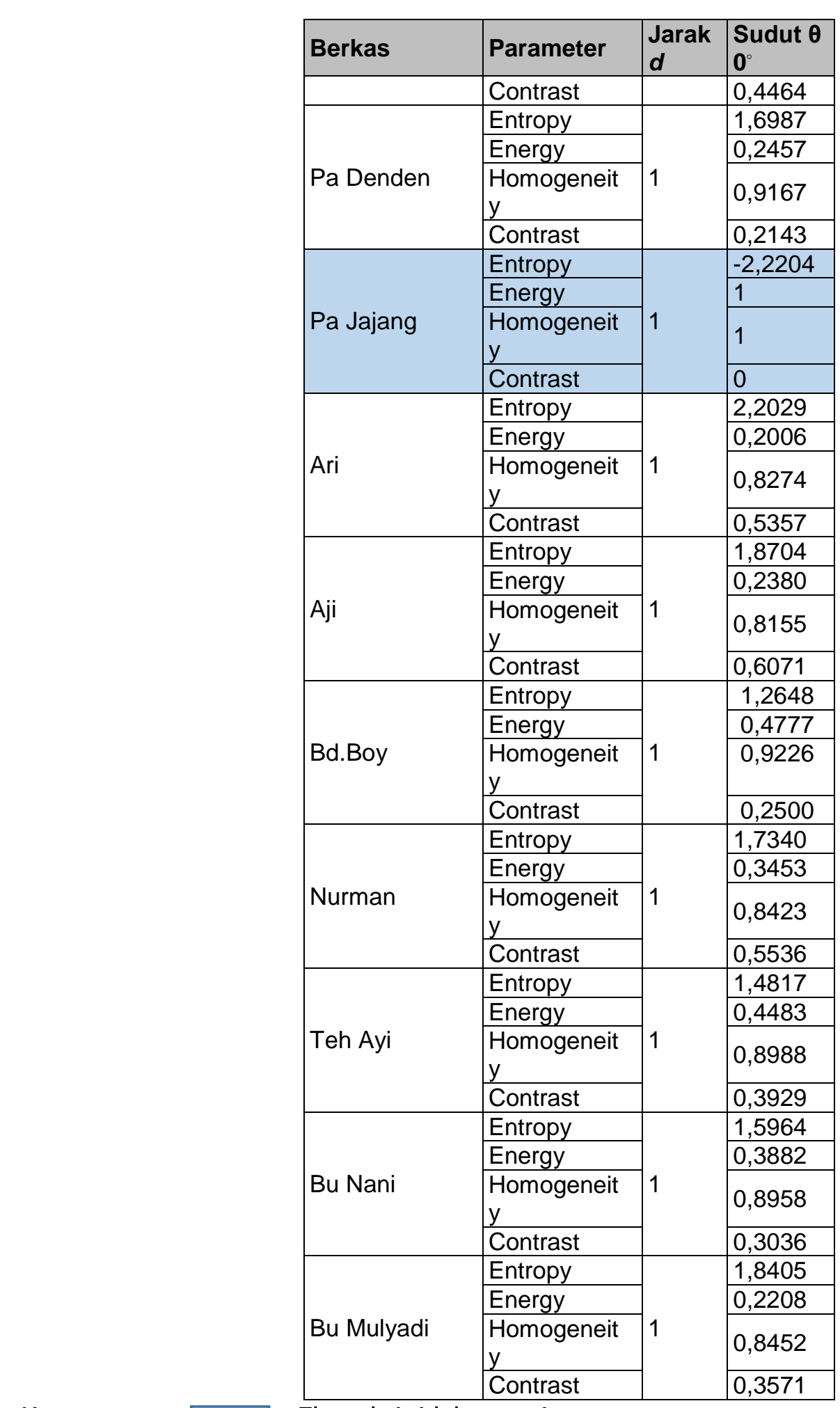

Keterangan :

Ekstraksi tidak sesuai

Tabel 3 menunjukan bahwa ada data yang tidak sesuai pada proses ekstraksi ciri dengan GLCM. Hal ini disebabkan bahwa pada proses deteksi lingkaran iris dan pupil yang tidak sesuai, maka akan mempengaruhi saat proses ekstraksi ciri. 


\subsection{Pengujian Klasifikasi Data Uji}

Tabel 5. Hasil pengujian euclidean pada data latih

\begin{tabular}{|l|l|}
\hline Berkas & Nilai Euclidean \\
\hline Rifqi & 0,023939 \\
\hline Bu Kikim & 0,10634 \\
\hline Bu Toha & 0,32393 \\
\hline Bu Ema & 0,19911 \\
\hline Bu Rais & 0,64174 \\
\hline Bu Setiono & 0,16168 \\
\hline Bu Tri & 0,079035 \\
\hline Pa Arya & 0,21585 \\
\hline Pa Ero & 0,16095 \\
\hline Pa Hilman & 0,64553 \\
\hline Pa Yudi & 0,051942 \\
\hline Oni & 1,853 \\
\hline Bu Andi & - \\
\hline Bu Nenden & 1,853 \\
\hline Dian & 0,07139 \\
\hline Pa Denden & 0,1574 \\
\hline Pa Jajang & 1,853 \\
\hline Ari & 0,2091 \\
\hline Bd.Boy & 0,14799 \\
\hline Aji & 0,46369 \\
\hline Nurman & 0,059699 \\
\hline Teh Ayi & 0,25067 \\
\hline Bu Nani & 0,11664 \\
\hline Bu Mulyadi & 0,080139 \\
\hline
\end{tabular}

Keterangan : $\square$ Vilai Euclidean tidak sesuai

Tabel 4 menunjukan bahwa ada data yang tidak sesuai pada proses perhitungan jarak dengan euclidean distance. Hal ini disebabkan bahwa pada proses ekstraksi ciri dengan GLCM tidak sesuai, maka akan mempengaruhi saat proses perhitungan jarak euclidean.

Tabel 6. Hasil pengujian MED pada data latih

\begin{tabular}{|l|l|l|l|l|}
\hline Berkas & $\begin{array}{l}\text { Intensitas } \\
\text { cahaya }\end{array}$ & Jarak & Hasil & Usia \\
\hline Rifqi & $17 \mathrm{~cd}$ & 22 & Kolesterol & 20 \\
\hline Bu Kikim & $29 \mathrm{~cd}$ & 23 & Kolesterol & 42 \\
\hline Bu Toha & $49 \mathrm{~cd}$ & 20 & Kolesterol & 45 \\
\hline Bu Ema & $29 \mathrm{~cd}$ & 25 & Normal & 53 \\
\hline
\end{tabular}


Tabel 6. Hasil pengujian MED pada data latih

\begin{tabular}{|l|l|l|l|l|}
\hline Berkas & $\begin{array}{l}\text { Intensitas } \\
\text { cahaya }\end{array}$ & Jarak & Hasil & Usia \\
\hline Bu Rais & $33 c d$ & 23 & Kolesterol & 50 \\
\hline Bu Setiono & $45 c d$ & 17 & Kolesterol & 68 \\
\hline Bu Tri & $33 c d$ & 17 & Kolesterol & 69 \\
\hline Pa Arya & $29 c d$ & 18 & Kolesterol & 67 \\
\hline Pa Ero & $33 c d$ & 18 & Kolesterol & 60 \\
\hline Pa Hilman & $28 c d$ & 23 & Kolesterol & 55 \\
\hline Pa Yudi & $34 c d$ & 23 & Kolesterol & 55 \\
\hline Oni & $22 c d$ & 14 & - & 35 \\
\hline Bu Andi & $16 c d$ & 29 & - & 23 \\
\hline Bu Nenden & $59 c d$ & 14 & - & 55 \\
\hline Dian & $16 c d$ & 26 & Kolesterol & 21 \\
\hline Pa Denden & $25 c d$ & 26 & Normal & 55 \\
\hline Pa Jajang & $22 c d$ & 29 & - & 45 \\
\hline Ari & $29 c d$ & 17 & Kolesterol & 23 \\
\hline Bd.Boy & $49 c d$ & 17 & Normal & 20 \\
\hline Aji & $29 c d$ & 20 & Normal & 23 \\
\hline Nurman & $33 c d$ & 20 & Normal & 32 \\
\hline Teh Ayi & $33 c d$ & 23 & Normal & 37 \\
\hline Bu Nani & $37 c d$ & 25 & Normal & 58 \\
\hline Bu Mulyadi & $48 c d$ & 25 & Normal & 54 \\
\hline Keterangan & Kasfika tidak & $55 a i$ & & \\
\hline
\end{tabular}

Keterangan : $\square$ Klasifikasi tidak sesuai

\section{Total Hasil Pengujian}

Pengujian dilakukan oleh 24 orang. Masing-masing citra matanya kemudian dilakukan pengujian terhadap data latih yang sudah disimpan. Tabel 5 menunjukan hasil pengujian klasifikasi dari citra mata berdasarkan intensitas cahaya mulai dari $16 \mathrm{~cd}$ sampai $59 \mathrm{~cd}$ dan jarak 14 sampai $25 \mathrm{~cm}$. Maka tingkat pengaruh pencahayaan dan jarak dalam persen dapat dihitung dengan cara:

$$
\frac{\text { Hasil yang sesuai }}{\text { Total seluruh uji coba }} \times 100
$$

Rumus 1 - rumus presntase keberhasilan

$\frac{17}{24} \times 100=70,83 \%$

\section{KESIMPULAN}

Berdasarkan hasil penelitian yang diperoleh dari pengujian sistem yang menerapkan metode GLCM dan metode MED, diperoleh kesimpulan sebagai berikut : 
1. Pada aplikasi pendeteksi kolesterol tingkat akurasi untuk sudut $\operatorname{GLCM}(\theta) 0^{\circ}$ dan jarak $(d)$ 1 mencapai 70,83\%.

2. Faktor yang mempengaruhi kegagalan penelitian diakibatkan tidak semua citra mata dapat diolah, ada beberapa citra mata yang tidak dapat terdeteksi lingkaran iris dan pupil secara utuh, karena pengambilan citra berada pada jarak yang terlalu dekat yaitu $<17$ atau terlalu jauh yaitu jarak $>=26 \mathrm{~cm}$.

3. Pengujian dengan variasi intensitas cahaya sangat mempengaruhi pada sistem sebesar $70,83 \%$.

\section{DAFTAR PUSTAKA}

[1] Jensen, Bernard. 1980 "Iridology Simplified, An Intoduction To The Sciene Of Iridology And Its Relation To Nutrition". USA, Calfornia.

[2] Maharani, Fina. 2013. "Perancangan Sistem Pola Kain Sarung Khas Makassar dengan Metode GLCM Berbasis Android". Bandung

[3] Prasetyo, Eko. 2012." Pengolahan Citra Digital dan Aplikasinya Menggunakan Matlab". Andi. Yogyakarta.

[4] Shalahuddin, M., Rosa A.S. 2013. "Rekayasa Perangkat Lunak Terstruktur dan Berorientasi Objek. Bandung, Informatika

[5] Syarif, Mulkan. 2012. "Olah Citra Dengan C\# Menggunakan Framework Aforge \& Accord".

[6] "_" "Analisis Tekstur Dengan Metode GLCM. 2011.https://utekqu.wordpress.com/2011/01/23/analisis-tekstur-dengan-metode-glcm/ Diunduh 24 Juli 2015 19:30

[7] "_, $\quad$ ".glcm. http://www.mathworks.com/help/images/gray-level-co-occurrencematrix-glcm.html. Diunduh 19 Agustus 2015 09:30.

[8] "' 2015 20:00

[9] "__", "Penyakit yang bisa diketahui melalui mata". https://m.facebook.com/notes/dahsyatnya-ilmu/penyakit-yang-bisa-diketahui-melaluimata/216219045092571/ Diunduh 24 Juli 2015 19:30 